\title{
Study on the boundary of development adjustment policy of B Oilfield
}

\author{
Simian Sun \\ Qing xin oil development limited liability company of Daqing Oilfield Company Ltd, Daqing 163000, China
}

\begin{abstract}
After more than ten years of water injection development, the water cut in the main block of oilfield B has increased rapidly and the production has decreased significantly. In view of the rapid rise of comprehensive water cut in the current oilfield, it is necessary to carry out the research on the development law of oilfield B and the reasonable boundary of various development adjustment indexes, so as to clarify the different production stages The development status and development index change law of the oilfield under different oil production rates provide an accurate and reliable theoretical basis for the rational development and adjustment of the oilfield. This paper provides theoretical basis and effective technical support for the adjustment in the middle and later stage of B oilfield development, which is of great significance to the stable production and long-term sustainable development of the oilfield.
\end{abstract}

\section{Study on reasonable limits of oilfield development indexes}

\subsection{Reasonable ratio of oil-water wells}

The production injection index ratio method is used to calculate the reasonable oil-water well number ratio. The reasonable oil-water well number ratio mainly depends on the ratio of water absorption index and liquid production index.

$$
R_{h}=\sqrt{\frac{1}{B_{o}\left(1-f_{w}\right)+f_{w}} \frac{I_{w}}{J_{L}}}
$$

In the formula:

$\mathrm{B}_{\mathrm{o}}$ - Crude oil volume factor, $\mathrm{m}^{3} / \mathrm{m}^{3}, 1.075$

$\mathrm{f}_{\mathrm{w}}$ - water cut

$\mathrm{I}_{\mathrm{w}}, \mathrm{J}_{\mathrm{L}}$ - water absorption index and liquid production index respectively, $\mathrm{t} / \mathrm{d} . \mathrm{MPa}$

The water absorption index and liquid production index of the oilfield over the years are counted, and the relationship between water absorption index, liquid production index and water cut is regressed. The water absorption index and liquid production index under different water cut are calculated by using the regressed equation, and then the reasonable oil-water well number ratio under different water cut conditions is obtained See (Figure 1, Figure 2and Table 1).

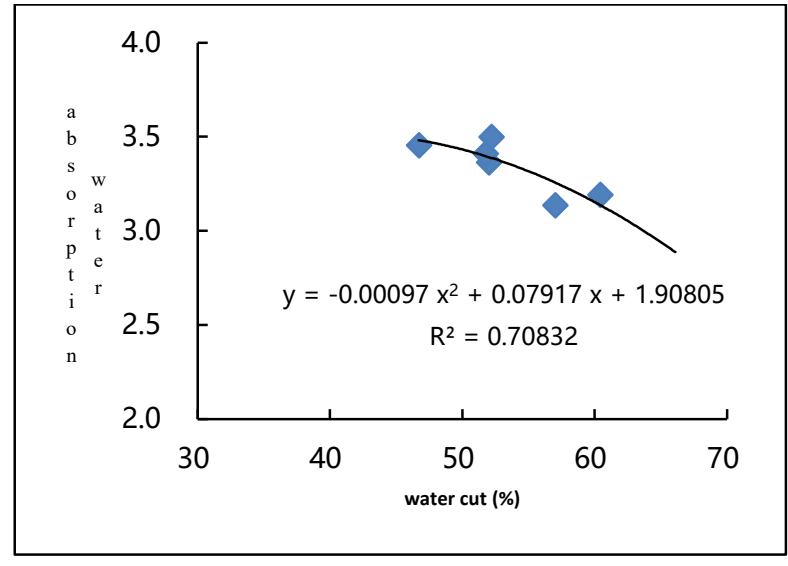

Fig. 1. Relationship between water absorption index and water content

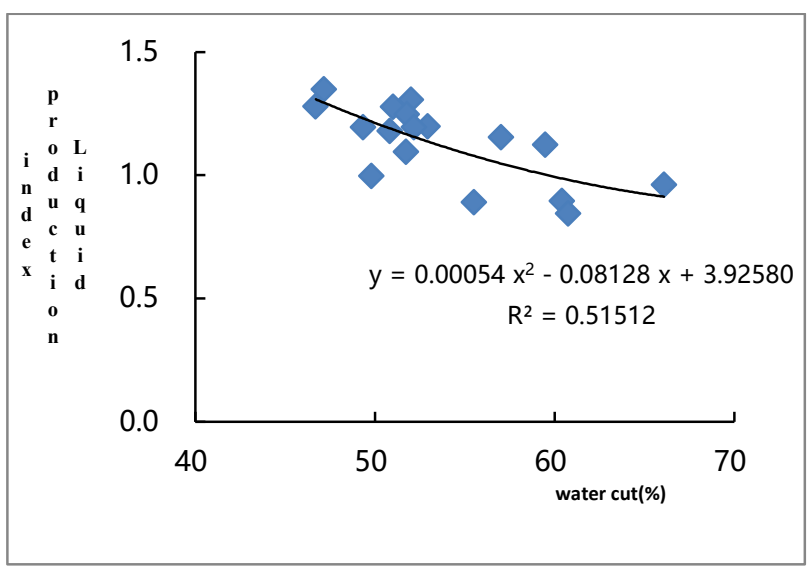

Fig. 2 Relationship between liquid production index and water cut 
Table 1. Ratio of oil-water wells under different water cut conditions

\begin{tabular}{|c|c|c|c|}
\hline $\begin{array}{c}\text { Water } \\
\text { cut } \\
(\%)\end{array}$ & $\begin{array}{c}\text { Water absorption } \\
\text { index } \\
\left(\mathrm{m}^{3} / \mathrm{MPa} . \mathrm{d}\right)\end{array}$ & $\begin{array}{c}\text { Liquid } \\
\text { production } \\
\text { index(t/MPa.d })\end{array}$ & $\begin{array}{c}\text { Oil water } \\
\text { well } \\
\text { number } \\
\text { ratio }\end{array}$ \\
\hline 60 & 3.166 & 0.993 & 1.8 \\
\hline 70 & 2.697 & 0.882 & 1.7 \\
\hline 80 & 2.034 & 0.879 & 1.5 \\
\hline 90 & 1.176 & 0.985 & 1.1 \\
\hline
\end{tabular}

According to the calculation, under the current water cut conditions, the reasonable oil-water well number ratio is 1.7 , and the actual oil-water well number ratio of $\mathrm{B}$ oilfield is 2.33 , so the injection production system still needs to be further optimized[1-5].

\subsection{Reasonable injection production ratio}

Whether the injection production is balanced can be reflected in the change of formation pressure. According to the change relationship between injection production ratio and formation pressure, a reasonable injection production ratio can be determined.

$$
\frac{d P_{R}}{d t}=a+b * I P R_{h}
$$

In the formula:

$d P_{R} / d t$-Formation pressure variation,Mpa ;

$a 、 b-$ Regression coefficient of equation.

Based on the actual data, the linear relationship between injection production ratio and total differential pressure change can be established, and the reasonable injection production ratio limit under different pressure changes can be obtained (Table 2). At present, the formation pressure of oilfield $\mathrm{B}$ is relatively low. According to the annual recovery of $0.3 \mathrm{MPa}$, the injection production ratio is 1.6, which is basically consistent with the actual situation (Fig. 3).

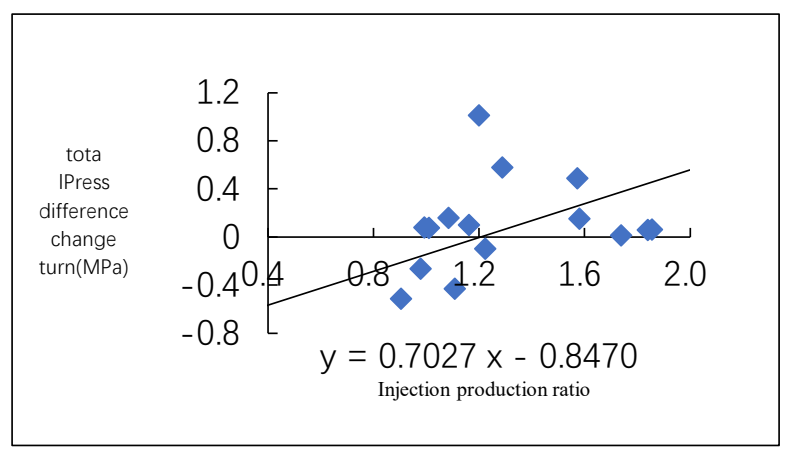

Fig. 3 Relationship between injection production ratio and total differential pressure
Table 2 Injection production ratio limit under different pressure recovery

\begin{tabular}{|c|c|c|c|c|c|c|c|c|}
\hline $\begin{array}{c}\text { Annual } \\
\text { pressure } \\
\text { change(MPa) }\end{array}$ & -0.2 & -0.1 & 0 & 0.1 & 0.2 & 0.3 & 0.4 & 0.5 \\
\hline $\begin{array}{c}\text { Reasonable } \\
\text { injection } \\
\text { production } \\
\text { ratio }\end{array}$ & 0.9 & 1.1 & 1.2 & 1.3 & 1.5 & 1.6 & 1.8 & 1.9 \\
\hline
\end{tabular}

\subsection{Reasonable production rate}

Oil production rate has an important impact on oilfield development effect, especially for bottom water or conglomerate reservoirs, too high oil production rate will cause rapid rise of water cut and sudden water flooding. Based on the relative permeability curve and water cut diversion equation, the relationship between oil production rate and water cut and water cut rise rate can be established. The expression of underground volume moisture content is:

$$
f_{w}=\frac{1}{1+\frac{\mu_{w} k_{r o}}{\mu_{o} k_{r w}}}
$$

In the formula:

$\mu_{o}, \mu_{w}$ oil phase and water phase viscosity respectively,mPa.s ;

$k_{r o}, k_{r w}$ Relative permeability of oil phase and water phase ;

According to relevant studies:

$$
\frac{k_{r o}}{k_{r w}}=a \cdot e^{-b \cdot S_{w}}
$$

The recovery degree can be expressed as:

From the above formulas:

$$
R=\frac{S_{w}-S_{w i}}{1-S_{w i}}
$$

$$
\begin{gathered}
R=A \cdot \ln \frac{1-f_{w}}{f_{w}}+B \\
A=-\frac{1}{b\left(1-S_{w i}\right)} \\
B=-\frac{1}{b\left(1-S_{w i}\right)} \ln \frac{\mu_{o}}{\mu_{w} a}-\frac{S_{w i}}{1-S_{w i}}
\end{gathered}
$$

Take the derivative of time $t$ at both ends of the above formula and take DT $=1 \mathrm{a}$ to obtain the calculation formula of oil production rate :

In the formula:

$$
v_{o}=\frac{1}{b\left(1-S_{w i}\right)} \cdot \frac{1-f_{w}}{f_{w}} \cdot F_{w}
$$

$v_{o}$ is the production rate, decimal

$F_{w}$ is annual appreciation, $\%$ 。

In order to obtain the relationship curve between theoretical oil production rate and water cut of oilfield $\mathrm{B}$, first fit and regress the relative permeability curve of the block to obtain $\mathrm{B}=28.68578$, and then obtain the relationship curve between oil production rate and water cut when the water cut of oilfield B rises in different years. It can be seen that when the water cut is the same, the higher the annual water cut appreciation, the greater the oil production rate; The effect of water cut on oil production rate is negative correlation when the water cut is less than $50 \%$, and then positive correlation. According to the statistics of the actual production data of oilfield B, the annual water cut appreciation in 2015 was 4.5 , the 
comprehensive water cut of the block was $66.7 \%$, the corresponding theoretical oil production rate was 1.02 , and the actual oil production rate of the oilfield was 1.04, slightly higher than the theoretical value.

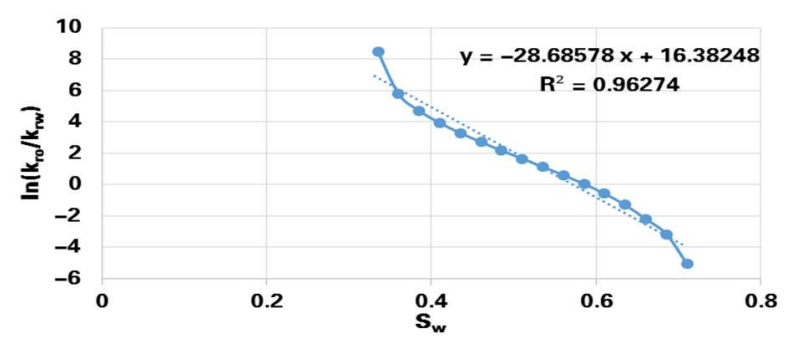

Fig.4 Relationship between natural logarithm of oil-water relative permeability ratio and water saturation

\section{Other indicators}

\subsection{Reasonable water injection intensity}

According to the principle of injection production balance, considering the reasonable injection production ratio when maintaining formation pressure, IPR:

In the formula:

$$
Q_{i}=I P R * Q_{L}
$$

Qi is the annual cumulative water injection of the block, $\mathrm{m}^{3}$;

$\mathrm{Q}_{\mathrm{L}}$ the annual liquid production of the block, $\mathrm{m}^{3}$;

IPRis the reasonable injection production ratio of the block。

According to the definition of water injection intensity, there are:

In the formula:

$$
Q_{i}=365 \alpha q_{i} H_{i}
$$

$\alpha$ Is the production hour rate of water injection well, decimal;

$q_{i}$ Is the average water injection intensity of the block, $\mathrm{m}^{3} / \mathrm{d} . \mathrm{m}$;

$H_{i}$ is the total thickness of water injection wells in the block,m

Production rate in block VO and annual average moisture content $f_{w}$ When w is certain, the annual liquid output can be expressed as:

In the formula:

$$
Q_{L}=\mathrm{N}_{\mathrm{p}} \frac{B_{o} V_{o}}{\rho_{o}\left(1-f_{w}\right)}
$$

$\mathrm{N}_{\mathrm{p}}$ Is the original geological reserves, $\mathrm{t}$;

$B_{o}$ Is the volume factor of crude oil, decimal ;

$V_{o}$ Is the production rate, decimal;

$\rho_{o}$ Is the density of crude oil, $\mathrm{kg} / \mathrm{m}^{3}$

According to the above formulas, the water injection intensity at a given reasonable oil production rate is:

$$
q_{i}=I P R * \mathrm{~N}_{\mathrm{p}} \frac{B_{o} V_{o}}{365 \alpha \rho_{o} H_{i}\left(1-f_{w}\right)}
$$

According to the above research, the reasonable injection production ratio of $\mathrm{B}$ oilfield is 1.6 , the reasonable oil production rate is 1.02 , and the original geological reserves are $1913.8 \times 10^{4} \mathrm{t}$, crude oil volume coefficient is 1.075 , crude oil density is 0.868 , block water cut is $66.7 \%$, the total perforation thickness of water injection well is $718.1 \mathrm{~m}$, and the production rate of water injection well is 0.733. By substituting the above formula, the reasonable water injection intensity is $3.94 \mathrm{~m}^{3} /$ D.M. Statistics show that the average water injection intensity of oilfield B in 2015 is $4.38 \mathrm{~m}^{3}$ / D.M, slightly higher than the reasonable value. The water injection intensity should be appropriately reduced according to the reasonable oil production rate and reasonable injection production ratio.

\subsection{Reasonable decline rate}

Natural decline rate and comprehensive decline rate are important indicators to reflect oilfield development. Natural decline refers to the production decline of old wells without measures in the previous year; Comprehensive decline refers to the production decline after the measures of old wells last year.

Namely:

$$
\begin{gathered}
D_{\mathrm{n}}=\frac{Q_{\mathrm{i}-1}-\left(Q_{\mathrm{i}}-Q_{\mathrm{xj}}-Q_{\mathrm{cs}}\right)}{Q_{\mathrm{i}-1}}=1-\frac{Q_{\mathrm{i}}-Q_{\mathrm{xj}}-Q_{\mathrm{cs}}}{Q_{\mathrm{i}-1}} \\
D_{\mathrm{R}}=\frac{Q_{\mathrm{i}-1}-\left(Q_{\mathrm{i}}-Q_{\mathrm{xj}}\right)}{Q_{\mathrm{i}-1}}=1-\frac{Q_{\mathrm{i}}-Q_{\mathrm{xj}}}{Q_{\mathrm{i}-1}}
\end{gathered}
$$

In the formula:

$\mathrm{D}_{\mathrm{n}}$-Natural decline rate of annual production of Oilfield Block, \% ;

$\mathrm{D}_{\mathrm{R}}$ - Comprehensive decline rate of annual production of Oilfield Block, $\%$;

$\mathrm{Q}_{\mathrm{i}-1}, \mathrm{Q}_{\mathrm{i}}$ Annual oil production in year i-1 and year $\mathrm{i}$ respectively, $10^{4} \mathrm{t} / \mathrm{a}$;

$\mathrm{Q}_{\mathrm{xj}}$-Production of new wells in the I year of the Oilfield Block, $10^{4} \mathrm{t}$;

$\mathrm{Q}_{\mathrm{cs}}$ - Production measures of old wells in the I year of Oilfield Block , $10^{4}$ t;

In a certain development stage, when the proportion of new well production and old well measure oil production is basically unchanged every year, the natural decline rate and comprehensive decline rate have a linear relationship.

$$
D_{\mathrm{n}}=a D_{\mathrm{R}}+b
$$

Where $\mathrm{a}$ and $\mathrm{b}$ are constants.

Using the above formula, the natural decline and comprehensive decline of B oilfield since 2006 are calculated respectively (table 3 ). Considering that oilfield $\mathrm{B}$ has been in the stable production stage since the tenth five year plan, the water cut rises slowly and the development situation is in a good state, therefore, the comprehensive decline rate and natural decline rate under different water cut conditions are characterized by establishing the relationship between comprehensive water cut and comprehensive decline rate and the relationship between comprehensive decline rate and natural decline rate. It can be seen that the water content is between $40 \%-60 \%$, the comprehensive decline is 19 $27 \%$, and the natural decline is $21-28 \%$; The water content is between $60-70 \%$, the comprehensive decline is $14-19 \%$, and the natural decline is $16-21 \%$; The water content is between $70-80 \%$, the comprehensive decline is $7-14 \%$, and the natural decline is $10-16 \%$. 
Table 3 Natural decline and comprehensive decline of B oilfield over the years

\begin{tabular}{|c|c|c|c|c|c|c|c|c|c|c|}
\hline $\begin{array}{c}\text { time } \\
\text { (year) }\end{array}$ & $\begin{array}{l}20 \\
06\end{array}$ & $\begin{array}{l}20 \\
07\end{array}$ & $\begin{array}{l}20 \\
08\end{array}$ & $\begin{array}{l}20 \\
09\end{array}$ & $\begin{array}{l}20 \\
10\end{array}$ & $\begin{array}{l}20 \\
11\end{array}$ & $\begin{array}{l}20 \\
12\end{array}$ & $\begin{array}{l}20 \\
13\end{array}$ & $\begin{array}{l}20 \\
14\end{array}$ & $\begin{array}{l}20 \\
15\end{array}$ \\
\hline $\begin{array}{l}\text { Natural } \\
\text { decline } \\
\text { rate(\%) }\end{array}$ & $\begin{array}{l}30 \\
.2\end{array}$ & $\begin{array}{c}24 \\
.0\end{array}$ & $\begin{array}{l}29 \\
.6\end{array}$ & $\begin{array}{c}24 \\
.9\end{array}$ & $\begin{array}{l}17 \\
.9\end{array}$ & $\begin{array}{c}20 \\
.0\end{array}$ & $\begin{array}{l}19 \\
.5\end{array}$ & $\begin{array}{r}26 \\
.6\end{array}$ & $\begin{array}{l}19 \\
.6\end{array}$ & $\begin{array}{l}18 \\
.2\end{array}$ \\
\hline $\begin{array}{c}\text { Compre } \\
\text { hensive } \\
\text { decline } \\
\text { rate } \\
(\%)\end{array}$ & $\begin{array}{l}29 \\
.7\end{array}$ & $\begin{array}{r}22 \\
.4\end{array}$ & $\begin{array}{l}26 \\
.7\end{array}$ & $\begin{array}{r}24 \\
.5\end{array}$ & $\begin{array}{l}16 \\
.4\end{array}$ & $\begin{array}{l}18 \\
.5\end{array}$ & $\begin{array}{l}17 \\
.7\end{array}$ & $\begin{array}{r}24 \\
.4\end{array}$ & $\begin{array}{l}16 \\
.2\end{array}$ & $\begin{array}{l}15 \\
.9\end{array}$ \\
\hline
\end{tabular}

\subsection{Water content rise}

Water cut rising rate is the rising value of water cut after $1 \%$ geological reserves are produced. It is an important index to evaluate the development effect of oil field. The relative permeability curve is used to draw the relationship curve between water cut and water cut rise under different permeability, which can intuitively reflect the water cut change law in different water cut stages. From the curve, when the water content is $50 \%$, the water content rise rate is the largest; The water content increases from 0 to $50 \%$, and the water content increases with the increase of water content; The water content increases from $50 \%$ to $98 \%$, and the water content decreases with the increase of water content. Under the same water cut conditions, the water cut increases with the increase of permeability. Therefore, the values of water content rise under different water content conditions are given (Table 4). The water content is between $40 \%-60 \%$, and the water content rise rate is $5.4 \%-5.6 \%$; The water content is between $60 \%-70 \%$, and the water content rise rate is $4.7 \%-5.4 \%$; The water content is $70 \%-80 \%$, and the water content rise rate is $3.6 \%-4.7 \%$. At present, the water cut of B oilfield is $66.7 \%$, and the water cut increase rate is $4.6 \%$, which is relatively reasonable.

Table 4 Variation of water cut rise rate in different water cut stages (theoretical)

\begin{tabular}{|c|c|c|c|c|c|c|c|c|c|c|}
\hline \multirow{2}{*}{$\begin{array}{c}\text { classific } \\
\text { ation }\end{array}$} & \multicolumn{9}{|c|}{ Water content rise under different water content(\%) } \\
\cline { 2 - 12 } & $\begin{array}{c}10 \\
\%\end{array}$ & $\begin{array}{c}20 \\
\%\end{array}$ & $\begin{array}{c}30 \\
\%\end{array}$ & $\begin{array}{c}40 \\
\%\end{array}$ & $\begin{array}{c}50 \\
\%\end{array}$ & $\begin{array}{c}60 \\
\%\end{array}$ & $\begin{array}{c}70 \\
\%\end{array}$ & $\begin{array}{c}80 \\
\%\end{array}$ & $\begin{array}{c}90 \\
\%\end{array}$ & $\begin{array}{c}98 \\
\%\end{array}$ \\
\hline $\mathrm{K}=20 \mathrm{M}$ & 1. & 2. & 2. & 3. & 3. & 3. & 2. & 2. & 1. & 0. \\
$\mathrm{D}$ & 2 & 2 & 9 & 4 & 5 & 4 & 9 & 2 & 2 & 3 \\
\hline & & & & & & & & & & \\
\hline $\mathrm{K}=120$ & 1. & 2. & 3. & 4. & 4. & 4. & 3. & 2. & 1. & 0. \\
$\mathrm{MD}$ & 5 & 7 & 6 & 1 & 3 & 1 & 6 & 7 & 5 & 3 \\
\hline $\mathrm{K}=250$ & 2. & 4. & 5. & 6. & 6. & 6. & 5. & 4. & 2. & 0. \\
$\mathrm{MD}$ & 4 & 4 & 8 & 6 & 8 & 6 & 8 & 4 & 4 & 6 \\
\hline $\mathrm{K}=500$ & 2. & 4. & 6. & 7 & 7. & 7 & 6. & 4. & 2. & 0. \\
$\mathrm{MD}$ & 6 & 6 & 1 & 7 & 3 & 7 & 1 & 6 & 6 & 6 \\
\hline normali & 2 & 3. & 4. & 5. & 5. & 5. & 4. & 3. & 2 & 0. \\
zation & 2 & 6 & 7 & 4 & 6 & 4 & 7 & 6 & 2 & 5 \\
\hline
\end{tabular}

\section{Conclusions and recommendations}

Through calculation, the policy limits of 7 important development indicators such as reasonable oil-water well number ratio, reasonable injection production ratio and reasonable flow pressure in B oilfield are obtained, which points out the direction for the subsequent optimization of water injection well adjustment and pressure system adjustment, improving the degree of reservoir production, and controlling the rate of production decline and water cut rise.

\section{References}

1. Du Qinglong, Zhu Lihong, Guo Junhui. A Quickand-Novel Method in Evaluating the Producing Performance of Single-Layer in the Multilayered Sandstone Oilfield. SPE131482, 2010.

2. M.D. Dunn. Simulation Based Dimension less Type Curves for Predjcting waterfloo Reeovery. SPE68839, 2001.

3. Liu Jin-feng, Ma Li-jun, Mu Bo-Zhong, et al. The field pilot of microbial enhanced oil recovery in a high temperature petroleum reservoir, Journal of Petroleum Science and Engineering, 2005, 48:265271.

4. Jang Long-Kuan, Chang $\mathrm{P}$ W, John E. Findley. Selection of bacteria with favorable transport properties through porous rock for the application of microbial-enhanced oil recovery[J]. Applied and Environmental Microbiology, 1983:1066-1072.

5. Cunningham A B, Sharp R R, Caccavo F, et al. Effects of starvation on bacterial transport through porous media[J]. Advances in Water Resources,2006.

6. Jiang Feng guang,Wang Xiao lin. Research on influence factors and theoretical value on recovery rate $[\mathrm{J}]$. Journal of Southwest Petroleum University, 2013,6(5):104-108.

7. Xue Wei. SPSS application and analysis statistic [M]. Beijing: Publishing House of Electronics Industry,2004:242-243.

8. Tang $\mathrm{Zi}$ chang, Cheng Lin song, Li Chun lan. Application of partial correlation analysis to oil recovery rate influencing factor analysis $[\mathrm{J}]$. Xinjiang Petroleum Geology,2010,31(4):423-425.

9. Jiang Han qiao, Yao Jun, Jiang Rui zhong. The fundament and practice of reservoir engineering [M]. .Dong ying, Shandong:China Petroleum University Press,2006:236.

10. Wang Peng. Research on reasonable production rate of low permeability injection reservoir [J]. Inner Mongolia Petrochemi-cal Industry,2012,6(3):139141.

11. Yu Qi tai, Li Wen xing. Production stabilizing pattern for waterflolding reservoir [J]. Petroleum Geology \& Oilfield Devel-opment in Daqing,1998,17(1):20-25.

12. 1CHEN Yuan qian, ZOU Cun you. Model's typical curve and its application for forecasting production and recoverable reserves of oilfields

13. WANG Xiao lin,CHANG Yu wen,DOU Hong en. The experiences from east Texas oilfield being of great significance for the large oilfield development in China[J]. Foreign Oilfield Engineering, 2010, 26(9): 15-19. 
14. SUN Long de,WU Xiao lin,ZHOU Wan fu,et al. Technologies of enhancing oil recovery by chemical flooding in Daqing oilfield,NE China[J]. Petroleum Exploration and Development, 2018, 45 (4) :636-645.

15. ZHOU Yun, ZHOU Fu jian, FENG Lian yong. A new model for predicting oil and gas production $[\mathrm{J}]$. Petroleum Geol-ogy and Oilfield Development in Daqing,2018,37(5):76-80. 